\title{
Perceptions of Firms Participating in a Circular Economy
}

\author{
Nicolò Cristoni ${ }^{1}$, Marcello Tonelli ${ }^{2}$
}

\begin{abstract}
Circular Economy (CE) is today a major concept within the sustainability debate (Geissdoerfer, Savageta, Bocken \& Hultinkb, 2017). Its theoretical arguments are widely accepted - especially at a cross-country institutional level - but businesses still seem reluctant to acknowledge it as a revenuemaking paradigm. This ongoing study aims to reveal where, along the value chain, firms are more unaware of CE best practice and/or reluctant to invest. After a comprehensive review of sustainable business models, the authors suggest a framework for circularity in business strategy as a beginning foothold on their research agenda. Next, the authors rely on expert informants to identify the most suitable areas in the value chain for the implementation of CE actions. Finally, an online free-access survey-like tool is launched to invite firms self-assessing (1) how relevant those identified areas are for their respective industries and (2) how CE-mature they feel regarding those areas. The initial results attest low consciousness of the $\mathrm{CE}$ potential across industries and even lower levels of maturity, especially by SMEs. Despite the growing evidence of Sustained Competitive Advantage (SCA) achieved by pioneering companies moving away from linear forms of production, through the development of new core competencies (Prahalad \& Hamel 1990), most firms still perceive CE as something not applicable to them or too costly and risky to implement.
\end{abstract}

Keywords: Circular economy (CE); core competencies; grounded theory; SMEs; sustainable business models; Sustained Competitive Advantage (SCA); value chain

\section{Introduction}

Environmental Sustainability is the ultimate challenge of the XXI century. The damage caused by private and public companies is undeniable and so is the role they need to start playing if we are to revert the current downward spiral of self-destruction (Benn, Dunphy \& Griffiths 2003; McDonough \& Braungart 2002). The fundamental problem is the industrial model standing at the roots of our economic system that is based on a take-make-waste paradigm (The Ellen McArthur Foundation 2012). In this linear form of production (1) natural resources are extracted from the Earth and (2) processed in manufacturing plants to become usable objects, which are then (3) sold to consumers, who eventually (4) discard them as waste in landfills or get incinerated. Each of these four steps causes a great deal of damage to environmental systems, primarily in terms of natural elements getting heavily polluted (air and water), being deprived of key components (soil) or irreversibly modified (forests). And the problem has progressively worsened as more and more countries worldwide have adopted this economic model. Today, we extract and consume roughly 95\% more materials than we did in 1880 and the numbers keep rising. The world aggregate material extraction rate of 35 billion tonnes

| ${ }^{1}$ Associate at Department of Sustainability Research and Development, WorlDynamics Pty. Ltd., Brisbane QLD 4012 Australia.

| ${ }^{2}$ Director at Department of Sustainability Research and Development, WorlDynamics Pty. Ltd., Brisbane QLD 4012 Australia. 
recorded in 1980 nearly doubled in three decades to the current 65+ billion tonnes (Giljum, Dittrich, Lieber \& Lutter 2014). What is even more alarming, today most assets end up being thrown away within just a few months from the time of purchase, resulting in waste generation levels exceeding 1.3 billion tonnes per year, and projected to surpass 2 billion tonnes by 2025 (The World Bank 2012). Despite all the damage caused to the natural environment and life wellbeing, the linear economic model does not contemplate any actions for the regeneration of the polluted natural ecosystems. As a result, particularly after 1950, "The Great Acceleration" in global economic activities has deepened the environmental footprint of the human enterprise, affecting the Earth system structure and functioning on multiple levels (Rockström, et al. 2009; Steffen, et al. 2015): higher-than-ever atmospheric concentration of greenhouse gases (particularly nitrous oxide, methane and carbon dioxide), widespread exploitation of fisheries, tropical rainforest and woodland loss, ever-growing demand for domesticated land and staggering rates of species extinct (Steffen, et al. 2004).

In the face of the many threats, challenges and opportunities posed by the linear way of production (The Ellen MacArthur Foundation 2015), a new economic model has emerged with strong impetus as the panacea for an economically successful and environmentally sustainable future (Ghisellini, Cialani \& Ulgiati, 2016). The Circular Economy (CE) is essentially an alternative industrial model (Bocken, Olivetti, Cullen, Potting \& Lifset 2017; Franconi, Bridgeland \& Webster, 2016; Lovins \& Braungart, 2014) where, by taking a systems approach (Webster 2013), industrial processes are not seen as the inevitable cause of natural resource exploitation, environmental pollution and waste generation. While the focus is still on making business operations profitable (The Ellen MacArthur Foundation 2013; Lacy \& Rutqvist, 2015), in a CE model this is achieved by embracing a number of innovative value-retaining strategies (Bocken, Bakker \& de Pauw, 2016) like design for prolonged use, modularity, utilization rate maximization through practices of sharing and reuse, refurbishment, remanufacturing, and recycling.

It is generally simple for firms to acknowledge the boundaries of our planet as well as the unsustainable future of many industrial practices; firms also recognize the growing attention of regulators and customers towards greener solutions, but very few of them perceive a monetary return attached to investments in CE. This is perhaps due to the great deal of innovation required to implement CE strategies within a business, together with the existing regulatory, financial and cultural barriers still preventing both supply and demand from fully grasping the benefits of a transition to $\mathrm{CE}$ products and processes (CEPS 2015). Just a few pioneering companies (Bakker, Wang, Huisman \& den Hollander, 2014; Niero, Hauschild, Hoffmeyer \& Olsen, 2017; Stål \& Jansson, 2017) - mostly large MNCs and start-ups - have shown success with their commitment to CE practices. The investment required is considerable, but so are the rewards and mounting evidence indicates applications in many key industrial sectors are possible (The Ellen MacArthur Foundation 2013; The Ellen MacArthur Foundation 2015). The process of stepping away from linear forms of production leads to the development of new core competencies along the value chain (De los Rios \& Charnley, 2016) and ultimately superior performance that cut costs, improve efficiency, meet advanced government regulations and the expectations of sophisticated customers, and represent a Sustained 
Competitive Advantage (SCA) against competitors. Of course, there is no single and structured way of making a business practice sustainable, but over the years a rather defined number of business models has surfaced as the most effective in concurrently delivering environmental as well as economic gains. Circular business models are sustainable business models, where the focus is on applying economically viable strategies to continually exploit products over many lifecycles and to use bio-based materials and renewable resources where possible (Bocken, Short, Rana \& Evans, 2014). The aim of this paper is to identify the business areas most suitable for the implementation of CE actions and to establish firms' perceptions of CE relevance of such actions for their industry as well as their own alleged CE maturity. The literature is divided into two macro areas: Section 2 reviews corporate competitiveness in terms of SCA and the development of core competencies; Section 3 focuses on sustainable business models and concludes by merging existing knowledge into a high-level framework for circularity in business strategy, a beginning foothold on the research. Section 4 presents the methods used; Section 5 discusses the results and Section 6 explains why they are deemed provisional.

\section{Literature on Corporate Competitiveness}

The core literature on business competitive advantage can be traced back to the early 80s when management authors began referring to it as the ability of a company, gained through its resources and capabilities, to reach a higher than normal level of performance (Gluck, Kaufman \& Walleck, 1980; Porter 1980). After debating for an often-greater importance of internal resources versus external considerations (i.e. industry structure), the conversation rapidly shifted towards how competitive advantage could be achieved and sustained, hence becoming a fertile research domain for the strategic management literature to proliferate (Collis \& Montgomery, 1995; Dierickx \& Cool, 1989; McGrath et al., 1996).

The fundamental argument presented was that a firm obtained a competitive advantage after properly combining resources and capabilities to develop a distinctive competence. Resources and capabilities can be physical assets like machinery, patents and even human resources (Barney \& Wright, 1998), but also intangibles and non-easily transferable assets like knowledge, experience, stakeholder relationships, and culture (Fiol 1991). Unfortunately, not all resources and capabilities are good enough to create a 'distinctive competence' and so it becomes essential to properly assess them prior to invest in them. The most established management tool used to evaluate resources and capabilities is the VRIO framework, introduced in 1991 by Barney, who is widely acknowledged as the main proponent of the Resource-Based View (RBV). Although capabilities were also considered in the model, they felt under and overly inclusive definition of "resources" (Kraaijenbrink Spender \& Groen, 2010) - as the name RBV attests - which to create SCA, had to be valuable, rare, imperfectly imitable and not substitutable (Collis \& Montgomery, 1995). The best place to look for the right resource candidates is the company's value chain (Barney 1991).

Since the RBV model was first presented, concepts in management theory central to corporate competitiveness matured and gained increasing attention, often leading to 
questioning the solidity of the RBV framework (Peteraf \& Barney, 2003). However, its central proposition of requiring valuable, rare, inimitable and non-substitutable resources and capabilities to achieve SCA remained valid and got shared by related concepts like core competencies (Prahalad \& Hamel, 1990) and dynamic capabilities (Teece, Pisano \& Shuen, 1997). The formers are defined as "the collective learning in the organization, especially how to coordinate diverse production skills and integrate multiple streams of technologies" (Prahalad \& Hamel, 1990, p. 84). This definition clearly highlights the enrichment from the original RBV explanation: it is not so much the value of individual resources that matters, but rather the synergistic combination of such resources and capabilities (Laurie, Doz \& Sheer, 2006). In the short term, strategy is constrained by the resources and capabilities available, so it is shaped by what the firm has. But over the long run, strategy is about renewing and adding resources and capabilities to develop distinctive competences that adapt quickly to changing environments (Alexander \& Martin, 2013; Zook, 2007). Because of the intense pressure of competing over costs and quality in the short term, most companies do not spend sufficient time developing a corporate view of the future and this leaves them without the core competencies necessary to tap into future opportunities.

The strategic importance of being able to responsively and purposefully adapt an organization's resource base to changing environments led to define such capacity as 'dynamic capabilities' (Teece, Pisano \& Shuen, 1997), thus differentiating them from the current operational capabilities of the company (Helfat et al., 2007). They are "the firm's processes that use resources - specifically the processes to integrate, reconfigure, gain and release resources - to match and even create market change" (Kraaijenbrink, Spender \& Groen, 2010, p. 357). The advent of dynamic capabilities was instrumental to step aside from the all-inclusive resources of the RBV and acknowledge the distinction between those resources that are inputs to the firm and the capabilities that enable the firm to select, deploy, and organize such inputs (Makadok 2001). Resources remain important for the life of the company, not per se, but because of the configuration conferred by dynamic capabilities (Ambrosini, Bowman \& Collier, 2009; Morgan, Vorhies \& Mason, 2009). Alongside the company's own internal resources, another source of input, especially concerning key technological capabilities, are external linkages (Coombs 1996). By using collaborative arrangements oriented toward technology access, companies can multiply internal resources and display a broader array of core competencies (Teece, Pisano \& Shuen, 1997) more rapidly and cost effectively.

When talking strategy, decisions must be made, and it is difficult to be all things for all people. A company must choose! For example, IKEA low cost and simple assembly appeals to a specific target of consumers, and so does BMW engineering excellence. However, when considering environmental sustainability, the potential market gets broader as it surpasses traditional segmentations. It touches young and old, male and female, rich and poor, sophisticated and simple buyer. A similar consideration can be made about combining multiple distinctive competencies (e.g. quality and effectiveness), an effort traditionally not pursued by many companies in a linear economy given the time and investment required to obtain them, but that circular thinking could facilitate. In a rapidly changing society like the one we are in, talking about competitive survival might perhaps sound more appropriate than SCA. Regardless of the term used, the 
significance of core competencies linked to environmental sustainability and the subsequent ability of a company to outperform competitors by doing things differently could be decisive in the years ahead.

\section{Literature on Sustainable Business Models}

A complete discussion of sustainable business models should arguably commence with the emergence back in the '80s of stakeholder theory (Freeman, 1984), as an alternative to pure profit maximization. The theory asserted that anyone, who affects or is affected by a firm's operations (e.g. employee, local communities, customers), has the right to be included in decision making, even if this means reducing profits for shareholders. Later attempts to broaden the spectrum of the constituencies that ought to be considered in shaping the direction of firms, focused on what was called the silent stakeholder i.e. the environment (Shrivastava, 1995; Solomon, 1997). In 1999, the authors of Natural Capitalism (Hawken, Lovins \& Lovins, 1999) put forward a four-step agenda to align ecological considerations with business operations, thus a sustainable business model that would favour both profitability and the environment.

This early work on conceptualizing Corporate Social Responsibility (or CSR), and attempting to place ecological considerations at the centre of business practices, has gradually evolved into more pragmatic approaches that see sustainability as a means to increase the competitive advantage of a firm, while concurrently benefitting its many stakeholders and thus contributing to sustainable development (Lüdeke-Freund, 2010). As the focus shifted from responsibility towards value creation, greater attention has been given to integrating social and environmental considerations at the very heart of a company business model (Porter \& Kramer, 2011).

With the notion of CE going mainstream, today the concept of 'sustainable business model' is being reshaped once again to accommodate the increasing concerns surrounding resource scarcity, a thriving middle-class, and fears of ecological thresholds being surpassed (Rockström et al., 2009; Steffen et al., 2015). At least four different typologies of circular business models appear in the corporate world: a switch towards environmentally friendly products and processes (net-zero innovation); selling services instead of goods, through servitization or product-service systems (Tukker 2015; Stål \& Jansson, 2017; Adrodegari, Saccani, Kowalkowski \& Vilo, 2017); implementing reverse cycle operations to extend the lifecycle of products; and recovering the residual value of materials through recycling or energy generation. While these novel approaches to business have been recognized as potentially helpful in driving a firm's competitiveness as well as contributing to environmental sustainability (Tukker \& Tischner, 2006), their successful implementation depends on being carefully tailored to the specific set of capabilities of each company, and be leveraged so that they connect modern technological advancements with the needs of the market in which the firm operates. Depending on the scenario, a company will favour one area of intervention or another. For example, a focus on innovative product design will imply placing ground-breaking design principles at the roots of the CE corporate strategy (den Hollander, Bakker \& Hultink, 2017). At least three broad approaches to circular design are rapidly emerging as clear alternatives to outdated linear solutions: green design, plan for durability and envisage 
reverse cycles (Bakker et al., 2014). Reverse cycle is the term used to identify the process of establishing and managing one or multiple flows of materials, components and products from the moment they get damaged, broken or discarded to their re-valorisation through repair, reuse, refurbishing, remanufacturing or recycling - and further introduction in the economic system. Thus, a company focusing on reverse cycles will be implementing actions aimed at collecting its used products and then establish effective post-value channels whereby items get processed according to the new function they will serve (Singh \& Ordonez, 2015). Green internal operations are circular interventions particularly relevant when the environmental impact of a company is largely dependent on the performance of its own sites and internal operations. In such circumstances CE principles can be leveraged, for example through the establishment of an Environmental Management System (EMS), to gradually reduce environmental externalities like greenhouse gas emissions, water use or pollution (Balta \& Woodside 1999; Wilson 2001). There is increasing evidence that a business case exists for leveraging circular solutions and establishing closed-loop processes through supplier engagement (The Ellen MacArthur Foundation 2014; Niero, et al., 2017). For some firms broad re-structuring of both internal operations and relationships with business partners are required, most notably if reverse cycles for product recovery are also established (CISL 2016). To do so, companies might need to expand the boundaries and scope of their sourcing activities well beyond business-as-usual. Internal alignment is the area of intervention that prompts a company to manage the widespread implications of embracing CE principles. It implies a change in culture touching all levels of the organization and successful implementation would result from getting managers and employees on board, getting buy-in from executives (CISL 2016), and ensuring strong cross-company alignment especially between design, marketing, sales and operations. As most organizations are still at the beginning of their circular journey, collaboration with external stakeholders can often bring multiple benefits (Niero et al., 2017; Lieder \& Rashid, 2016), especially in industries where CE implementation is particularly difficult (e.g. due to complex and dispersed supply chains or heavy reliance on virgin materials). Moreover, the establishment of a novel circular business model is likely to impact the organization well beyond its traditional boundaries and current operations. Hence, for many firms, implementing a circular strategy will inevitably mean collaborating with a complex web of stakeholders as opposed to managing simple transactions in a linear fashion.

The framework below is meant as a beginning foothold on the research (Glaser \& Strauss, 1967). It developed from a comprehensive review of the existing literature on circular business models and was strengthened by the professional experience in management consulting matured over the years by the two authors. It outlines in sequence from left to right: the four high-level guiding $\mathrm{CE}$ principles, the six CE business objectives that generally lead to major opportunities for CE adoption; and the six areas of intervention for operationalizing the circular opportunities identified. 


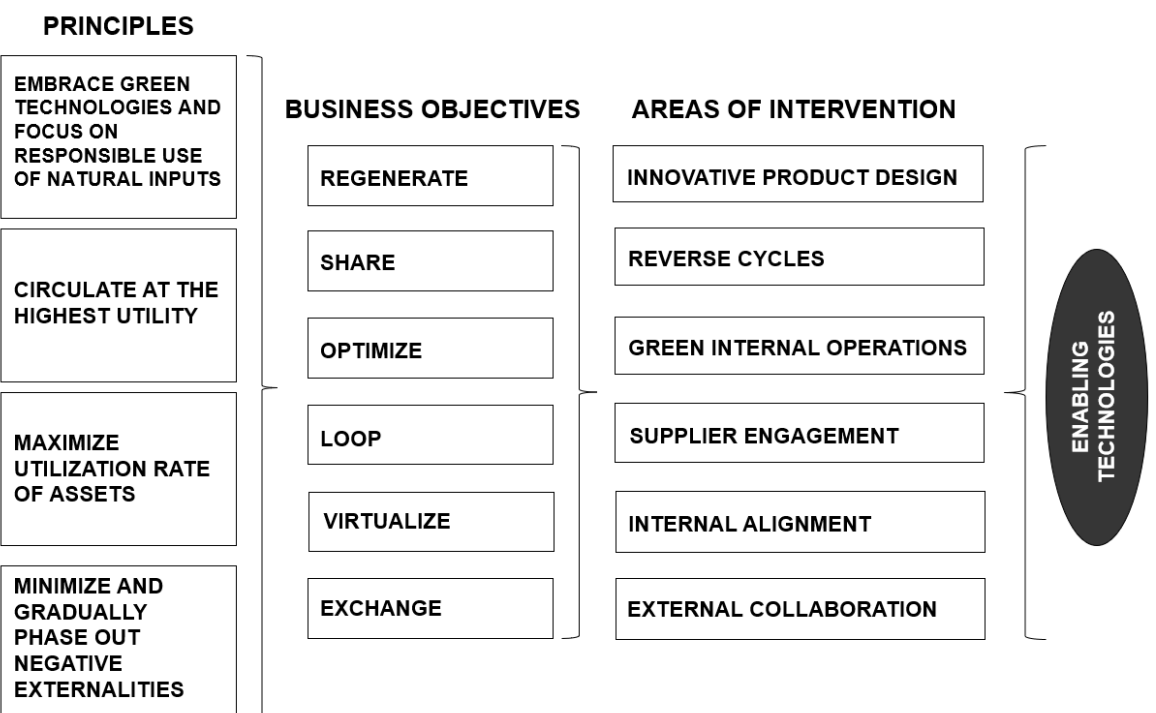

Fig.1. Framework for Circularity in Business Strategy

The growing interest of society towards sustainability is confirmed by the rapid expansion of the literature discussing sustainability-related topics, and CE is certainly becoming a prime concept within that conversation. However, even though there is a lot of positive and promising talk happening, many companies still perceive $\mathrm{CE}$ as something not applicable to them and/or too innovative, with high risks and prohibitive costs involved. From this consideration the following questions were derived:

1. What business areas are most suitable for the implementation of strategies based on principles of circularity?

2. Do companies perceive CE strategies in those areas to be relevant for their respective industries (i.e. capable of providing a competitive advantage)?

a. Are there differences in perceptions based on company size?

b. Are there differences in perceptions across industries?

c. Are there differences in perceptions across countries?

d. Are there differences in perceptions based on business category (e.g. manufacturer, distributor, wholesaler, service provider)?

e. Are there differences in perceptions based on customer target (e.g. B2B, B2C)?

What level of maturity do companies feel they have achieved in terms of their CE abilities, policies, and internal programmes compared to what would be possible?

\section{Methodology}

Given the brief history of the field and the absence of consolidated theoretical frameworks, the research design opted for this paper was mostly based on inductive reasoning and sought to derive broad generalizations from specific observations. Interviews and questionnaires were used as data sources to come up with a grounded theory (Strauss \& Corbin, 1994) capable of answering the research questions. The first 
step in designing the research framework was to identify a purposive sample (Glaser \& Strauss, 1967; Strauss, 1987): business practitioners with some degree of knowledge or expertise in CE. The aim was to come up with a sample large enough to cover most of the industrial sectors in Italy. Country selection was solely based on accessibility advantages and the limited funding available (convenience sampling). After initial contacts were made with personal acquaintances, the sample was then expanded to reach 30 individuals by implementing elitist snowball techniques (Verschuren \& Doorewaard, 1999). The objective here was to increase the likelihood of finding divergent information and gaining access to a greater number of confirming or weakening perspectives.

This sample of 'CE-expert' practitioners was then employed to gather data regarding the business areas most suitable for the implementation of strategies based on principles of circularity. The choice of interview questions and how to frame them, as well as the selection of certain topics for detailed analysis was based on the researchers' ongoing study of existing CE instruments and insights from professional experiences (Glaser \& Strauss, 1967; Strauss \& Corbin, 1990). The previously presented framework for circularity in business strategy (Figure 1) was shared with the interviewees prior to the meeting to introduce the context and prompt thought through responses to open-ended unstructured questions (Douglas, 1985; Saunders, Lewis \& Thornhill, 2007) build around a typical value chain: design $>$ sourcing $>$ production $>$ distribution $/$ shipment $>$ use $>$ end use.

Content analysis was performed manually (analysis of phrases) and separately by two researchers, before being circulated for comments. Upon grouping analysed data into concepts, 17 different business areas for CE strategies were identified. Each one was given a definition, it was linked to specific business benefits, and exemplified with fitting cases of best practice.

The last step of the research design was to broadly disseminate the 17 business areas for CE strategies and begin testing practitioners' perceptions for (1) the relevance they had for the industry they belonged to and (2) their own degree of maturity towards them. An online questionnaire ${ }^{1}$ was created and released with free access, hence adopting a random sampling technique. Any company could register by filling a simple form and then conduct a CE self-assessment (WorlDynamics, 2017). The exercise required ranking relevance (for industry) and maturity (at the firm-level) for each of the 17 areas for circular action. A 5-point Likert-type scale was used.

\section{Results}

\subsection{Business Areas for Implementing CE Strategies}

The collection, study and clustering of expert opinions led to the identification of 17 areas of circular action that could most significantly modify business-as-usual operations. These are presented in the diagram below and grouped according to the steps of a typical value chain.

\footnotetext{
${ }^{1}$ Circular Readiness Assessment Tool http://www.worldynamics.com/circular_economy/web/assessment/main
} 


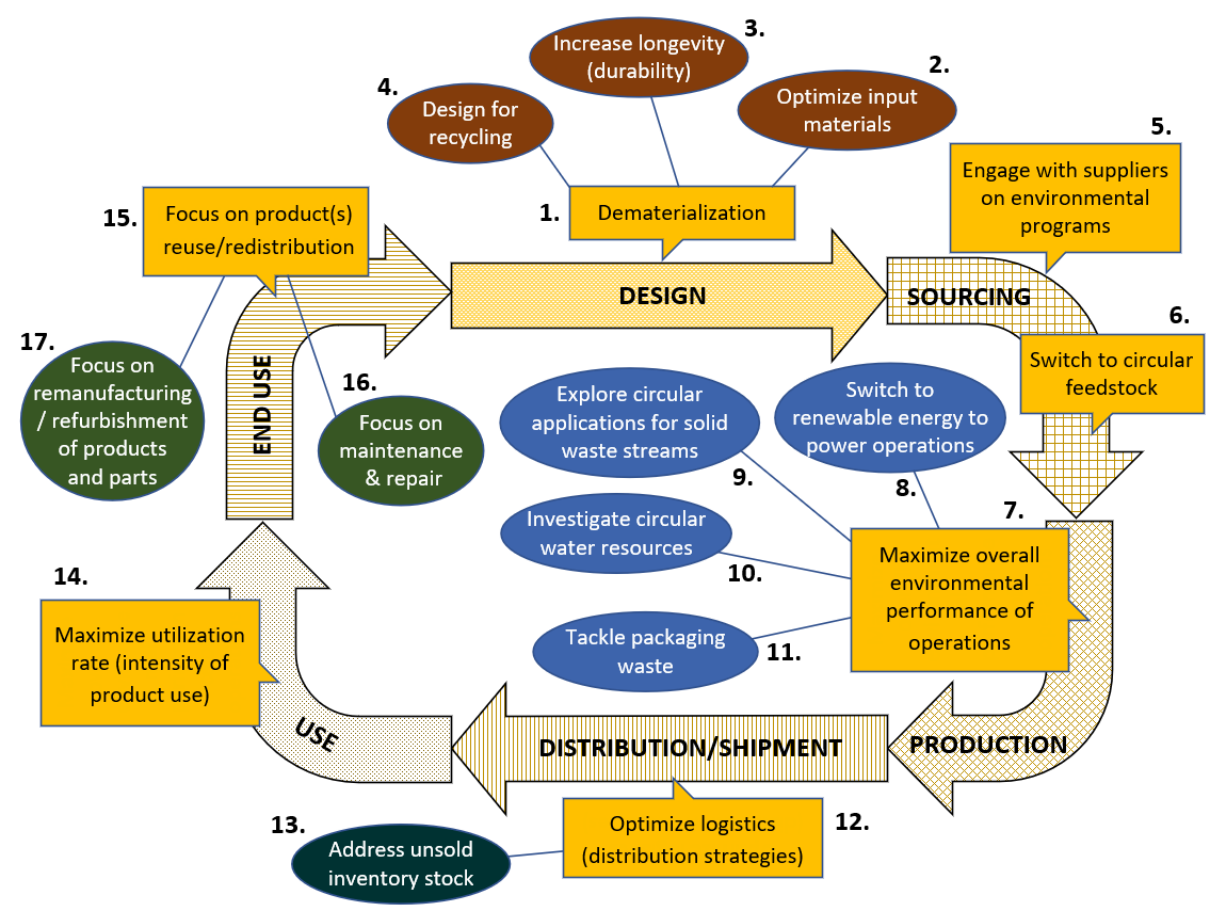

Fig. 2. The Key Areas of Circular Action

During the interview process, the most challenging step in the value chain to assess and unpack into practical circular actions was DESIGN. That difficulty, primarily due to the variety of perspectives offered by the interviewees, is in line with the vast attention given by the literature when compared to other phases (Bakker et al. 2014; Mendoza, Sharmina, Gallego-Schmid, Heyes \& Azapagic, 2017) and arguably justified by a recognition that changes in product design have clear and direct consequences on the entire value chain (De los Rios \& Charnley 2016). Item \#4 "Design for recycling" was initially included, just as "Recycling" under END-USE, primarily for consistency with the other reverse cycle operations clustered under that heading. However, after careful analysis, some experts suggested it would have been sounder to move recycling under DESIGN, notably because, contrary to reuse, repair, refurbishing and remanufacturing, usually the recycling of a product is not processed by the company producing it, but rather by specialized external firms. According to this view, "Design for recycling" was created to denote the design efforts put in place when developing products that are easier to recycle. PRODUCTION was another area that required substantial analytical work to comprehensively identify and evaluate all the possible circular activities a company can pursue. And once again the literature confirmed how manufacturing had traditionally been an area highly investigated under the CE perspective (Lieder \& Rashid 2016).

Overall, the 17 circular actions were defined according to a broad understanding of the CE as being an umbrella concept (Blomsma \& Brennan 2017) covering not only activities aimed at phasing out waste and pollution while keeping products and materials 
in use, but also focusing on regenerating natural systems (The Ellen MacArthur Foundation 2014). As such, besides the "core" CE activities linked to the establishment of reverse cycle operations and closed-loop systems, there has been unanimous agreement among the experts involved on the inclusion of a number of CE actions primarily concerned with minimizing environmental externalities caused by emissions and the use of toxic substances ("Optimise input materials", "Engage Suppliers On Environmental Programs", "Maximize Overall Environmental Performance Of Operations" and "Switch To Renewable Energy To Power Operations").

\subsection{Firms Perceptions of CE Efforts}

Over a period of 3 months, a total of 38 companies registered to take the CE self-assessment test. All these all were based in Italy, with $2 / 3$ of them operating businessto-business, while the rest were business-to-consumer (B2C). Most of these companies (roughly 92\%) were SMEs operating as manufacturers in their respective value chains. The table below offers an overview of the aggregate results collected thus far.

Table 1. Summary of Firms Perceptions Towards CE Efforts

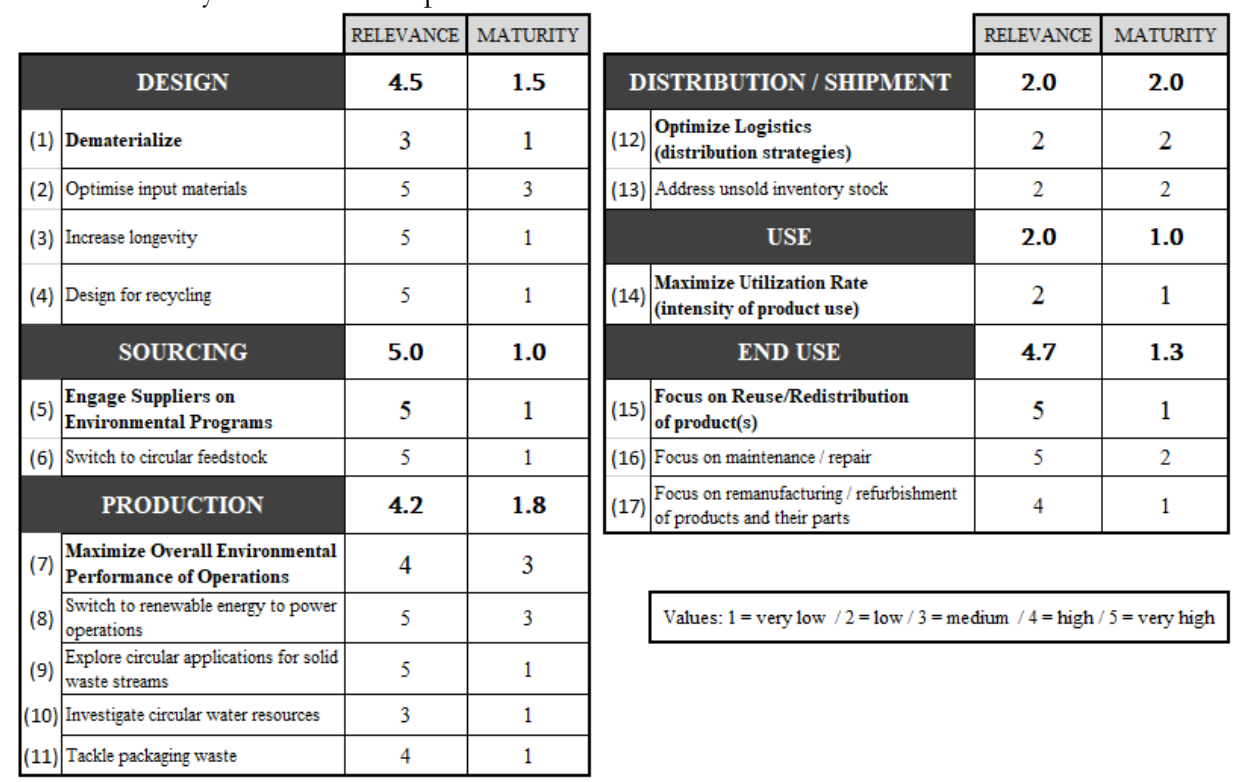

Relevance was the industry-level indicator of how firms perceive the 17 circular actions might have a positive impact on the overall environmental performance of their industries. According to the feedback received, the areas recognized to be potentially transformed by an industry-wide implementation of circular principles were DESIGN, SOURCING, PRODUCTION and END USE. This was little surprise, given most respondents being SMEs operating in manufacturing sectors (e.g. textile, consumer products and food), with elaborated supply chains, environmentally impactful operations and overall poor closed-loop performance.

As for Maturity - the firm-level indicator used to self-assess one's own operations on the 
17 circular actions - SHIPMENT, PRODUCTION, and DESIGN scored slightly higher than the rest, but still in the low range. The average maturity for SHIPMENT was low because generally perceived as being not so relevant, which is consistent with green shipment activities usually being pursued only by large multinationals that can afford investing in such projects. However, there have been instances of SMEs communicating that they had taken some initial steps to address their unsold inventory stocks (13) by, for example, regularly donating to local charities. Other firms have been engaged by their clients to improve their logistic operations (12). With respect to PRODUCTION, it is worth mentioning that some respondents scored relatively high to both items (7) and (8), for they had either embarked on an environmental certification path (EMAS or ISO14001, which both the setting up of an EMS), or had installed renewable energy systems (primarily solar) to power their manufacturing operations (even though only partially). When it came to DESIGN, it must be said that a considerable number of respondents supplied products to clients in the business-to-business (B2B) arena, and therefore often these firms received mandatory design instructions on how to create the product directly from their customers. Therefore, the adoption of circular design principles was automatically prevented to them. However, a considerable number of respondents gave a medium rating to the optimization of input materials (2) for they communicated that many toxic substances used in production, like glues and paints, have been replaced over the last few years with ecological and bio-based alternatives.

SOURCING, USE, and END-USE proved to be the weakest areas, with average scores of 1. A rational similar the one used for DESIGN also applied to the USE and ENDUSE phases, for usually the companies lost track of their products after being sold to clients. Regarding SOURCING, most respondents based their rating on the acknowledgement that they lacked the resources and capabilities to engage suppliers on environmental programs (5) or to partner up with them to find circular feedstock solutions (6).

\section{Conclusions}

This paper is part of an ongoing research project aiming to identify the business areas most suitable for the implementation of CE actions and to establish firms' perceptions of CE relevance for their industries as well as their own alleged CE maturity. While the preliminary results show a picture consistent with the findings of recent studies, they are based on a still limited dataset and need to be pondered as a first attempt at informing on the subject. Further validation is necessary and will be built overtime as the tool progresses through advanced phases of development and adoption. The prospect, once the limitations of sample size have been overcome, is to allow for statistically meaningful aggregate analyses based on firm size, industry type, location, category (e.g. manufacturer, distributor, wholesaler, service provider), and customer target (B2B, B2C).

In its current form, the study substantiates the view shared by academic literature and practice: a swift and widespread prosperity of CE principles is challenging. Apparently, the common perception is still anchored to $\mathrm{CE}$ efforts aiming at weakening profitmaximization by placing excessive attention towards reaching new heights in 
environmental protection. This erroneous understanding represents a serious threat to implementation as theoretical arguments can only go so far in presenting a valid case for CE. To help all companies (especially SMEs) appreciate the full potential of circularity for business, it would seem highly beneficial to incorporate novel CE notions into conventional conversations surrounding the strategic management process (definition, evaluation and realization) and its analytical tools.

\section{References}

Adrodegari, F., Saccani, N., Kowalkowski, C. \& Vilo, J. (2017). PSS business model conceptualization and application. Production, Planning \& Control. The Management of Operations, 28 (15), pp.1251-1263.

Alexander, A.T. \& Martin, D.P. (2013). Intermediaries for open innovation: A competence-based comparison of knowledge transfer offices practices. Technological Forecasting and Social Change, 80(1), pp.38-49.

Ambrosini V. Bowman C. \& Collier N. (2009). Dynamic capabilities: an exploration of how firms renew their resource base. British Journal of Management, 20 (S1), pp. S9-S24.

Balta, W. \& Woodside, G. (1999). IBM's experience implementing ISO 14001 on a global basis: Does ISO 14001 achieve its intended goals? Journal of the Forum for Environmental Law, Science, Engineering and Finance 3(9), 1-10

Bakker, C., Wang, F., Huisman, J., \& den Hollander, M. (2014). Products that go around: Exploring product life extension through design. Journal of Cleaner Production 69 pp. 10-16.

Barney, J. (1991). Firm resources and sustained competitive advantage. Journal of Management, 17(1), pp.99120.

Barney, J.B. \& Wright, P.M. (1998). On becoming a strategic partner: The role of human resources in gaining competitive advantage. Human Resource Management, 37(1), p.31.

Benn, S., D. Dunphy, \& Griffiths A. (2014). Organizational Change for Corporate Sustainability. Third edition. New York, Routledge.

Blomsma, F., \& Brennan, G. (2017). The Emergence of Circular Economy: A New Framing Around Prolonging Resource Productivity. Journal of Industrial Ecology, 21 pp. 603-614.

Bocken, N.M.P., Short, S.W., Rana, P. \& Evans, S. (2014). A literature and practice review to develop sustainable business model archetypes. Journal of cleaner production, 65, pp.42-56.

Bocken, N. M. P., Bakker, C. \& de. Pauw, I. (2016). Product design and business model strategies for a circular economy. Journal of Industrial and Production Engineering 33(5), pp. 308-320.

Bocken, N. M. P., Olivetti, E. A., Cullen, J. M., Potting, J. \& Lifset, R. (2017). Taking the Circularity to the Next Level: A Special Issue on the Circular Economy. Journal of Industrial Ecology, 21 pp. 476-482.

CISL - Cambridge Institute for Sustainability Leadership (2016). Collaboration for a closed-loop value chain. Transferable learning points from the REALCAR project.

CEPS - Centre for European Policy Studies (2015). The Circular Economy: Barriers and opportunities for SMEs. Working doc. No.412 September

Collis, D.J. \& Montgomery, C.A. (1995). Competing on Resources: Strategy in the 1990s. Harvard Business Review, 73(Jul-Aug), pp.118-128.

Coombs, R. (1996). Core competencies and the strategic management of R\&D. R\&D Management, 26(4), pp.345-355.

De los Rios, I.C. \& Charnley, F.J. (2016). Skills and capabilities for a sustainable and circular economy: The changing role of design. Journal of Cleaner Production, 160 (1), pp. 109-122.

den Hollander, M. C., Bakker, C. A., \& Hultink, E. J. (2017). Product Design in a Circular Economy: Development of a Typology of Key Concepts and Terms. Journal of Industrial Ecology, 21 pp. 517525.

Dierickx, I. \& Cool K. (1989). Asset stock accumulation and sustainability of competitive advantage. Management Science, 35(12), pp.1504-1511.

Douglas, J. D. (1985). Creative Interviewing. Beverly Hills, CA: Sage.

Fiol C.M. (1991). Managing culture as a competitive resource: An identity-based view of sustainable competitive advantage. Journal of Management 17(1), pp.191-211. 
Franconi, E., Bridgeland, B., \& Webster, K. (2016). A New Dynamic 2: Effective Systems in a Circular Economy. Isle of Wight, UK: Ellen MacArthur Foundation Publishing.

Freeman, E. (1984). Strategic Management: A Stakeholder Approach. Boston: Pitman.

Geissdoerfer, M., Savaget, P., Bocken, N., \& Hultink, E. (2017). The Circular Economy - A new sustainability paradigm? Journal of Cleaner Production, 143 (1), pp. 757-768.

Ghisellini, P., Cialani, C., \& Ulgiati, S. (2016). A review on circular economy: The expected transition to a balanced interplay of environmental and economic systems. Journal of Cleaner Production 114: 11-32.

Giljum, S., Dittrich, M., Lieber, M., \& Lutter, S. (2014). Global Patterns of Material Flows and their SocioEconomic and Environmental Implications: A MFA Study on All Countries World-Wide from 1980 to 2009. Resources 3 pp. 319-339.

Glaser, B. G. \& Strauss A. (1967). The Discovery of Grounded Theory. Chicago: Aldine.

Gluck, F.W., Kaufman, S.P. \& Walleck, A.S. (1980). Strategic management for competitive advantage. Harvard Business Review, July.

Hawken, P., Lovins, A. B., \& Lovins, L. H. (1999). Natural capitalism: The next industrial revolution. Earthscan.

Helfat C., Finkelstein S., Mitchell W. \& Peteraf M. (2007). Dynamic Capabilities: Understanding Strategic Change in Organizations. Blackwell: Oxford, UK.

Kraaijenbrink, J., Spender, J.C. \& Groen, A.J. (2010). The resource-based view: a review and assessment of its critiques. Journal of management, 36(1), pp.349-372.

Lacy, P. \& Rutqvist, J. (2015). Waste to Wealth: The Circular Economy Advantage. Hampshire, Palgrave MacMillan.

Laurie, D.L., Doz, Y.L. \& Sheer, C.P. (2006). Creating new growth platforms. Harvard Business Review, 84(5), pp.80-90.

Lieder, M. \& Rashid, A. (2016). Towards circular economy implementation: A comprehensive review in context of manufacturing industry. Journal of Cleaner Production 115 pp. 36-51.

Lovins, A. \& Braungart, M. (2014). A New Dynamic - Effective Business in a Circular Economy. Isle of Wight, UK: Ellen MacArthur Foundation Publishing.

Lüdeke-Freund, F., (2010). Towards a Conceptual Framework of Business Models for Sustainability. Knowledge collaboration \& learning for sustainable innovation, Delft, The Netherlands.

Makadok, R. (2001). Towards a Synthesis of Resource-Based and Dynamic Capability Views of Rent Creation. Strategic Management Journal, 22 pp.387-402.

McDonough, W. \& Braungart, M. (2002). Cradle to cradle: Remaking the Way We Make Things. New York, North Point Press.

McGrath, R. G., M-H. Tsai, S. Venkataraman \& MacMillan I.C. (1996). Innovation, competitive advantage and rent: A model and test. Management Science, 42(3), pp. 389-403.

Mendoza, J. M. F., Sharmina, M., Gallego-Schmid, A., Heyes, G. \& Azapagic, A. (2017). Integrating Backcasting and Eco-Design for the Circular Economy: The BECE Framework. Journal of Industrial Ecology, 21 pp. 526-544.

Morgan N.A., Vorhies D.W. \& Mason C.H. (2009). Market orientation, marketing capabilities, and firm performance. Strategic Management Journal, 30(8), pp.909-920.

Niero, M., Hauschild, M. Z., Hoffmeyer, S. B. \& Olsen, S. I. (2017). Combining Eco-Efficiency and EcoEffectiveness for Continuous Loop Beverage Packaging Systems: Lessons from the Carlsberg Circular Community. Journal of Industrial Ecology, 21(3) pp. 742-753.

Peteraf, M.A. \& Barney, J.B. (2003). Unraveling the resource- based tangle. Managerial and decision economics, 24(4), pp.309-323.

Porter, M.E. (1980). Competitive strategy: Techniques for analyzing industries and competition. New York: Free Press.

Porter, M. E. \& Kramer M. R. (2011). Creating Shared Value. Harvard Business Review, 89(1-2), pp. 62-77.

Prahalad, C.K. \& Hamel G. (1990). The Core Competence of the Corporation. Harvard Business Review, 68(3), pp.79-91.

Rockström, J., Steffen, W. L., Noone, K., Persson, A., Chapin III, F. S., Lambin, E., ... Foley, J. (2009). Planetary boundaries: exploring the safe operating space for humanity. Ecology and Society, 14(2): 32.

Saunders, M., P. Lewis, \& Thornhill A. (2007). Research Methods for Business Students. Fourth edition. Harlow, UK: Pearson Education Limited.

Shrivastava, P. (1996). Ecocentric management for a risk society. Academy of management review, 20(1), pp. 118137. 
Singh, J. \& Ordoñez, I. (2016). Resource recovery from post-consumer waste: important lessons for the upcoming circular economy. Journal of Cleaner Production, 134 pp. 342-353

Solomon, R. C. (1997). It's Good Business: Ethics and Free Enterprise for the New Millennium. Rowman \& Littlefield Publishers, Inc.

Stål, H. I., \& Jansson, J. (2017). Sustainable Consumption and Value Propositions: Exploring ProductService System Practices Among Swedish Fashion Firms. Sustainable Development 25(6), pp. 546558.

Steffen, W., Sanderson, A., Tyson, P.D., Jäger, J., Matson, P.A., Moore III, B., .. Wasson, R.J. (2004). Global Change and the Earth System: A Planet Under Pressure. Springer-Verlag Berlin Heidelberg New York.

Steffen, W., Richardson, K., Rockström, J., Cornell, S. E., Fetzer, I., Bennett, E. M., ... Sörlin, S. (2015). Planetary boundaries: Guiding human development on a changing planet. Science 347(6223).

Strauss, A.L. (1987). Qualitative Analysis for Social Scientists. Cambridge: Cambridge University Press.

Strauss, A. \& Corbin J. (1990). Basics of qualitative research. Newbury Park, CA: Sage.

Strauss, A. \& Corbin J. (1994). Grounded Theory Methodology: An Overview. In The Handbook of Qualitative Research, ed. N. K. Denzin and Y. S. Lincoln, 273-285. Thousand Oaks: Sage Publications.

Teece DJ, Pisano G, \& Shuen A. (1997). Dynamic capabilities and strategic management. Strategic Management Journal, 18 pp.509-533.

The Ellen MacArthur Foundation, (2012). Towards the circular economy: Economic and business rationale for accelerated transition. Vol. 1. The Ellen MacArthur Foundation.

The Ellen MacArthur Foundation, (2013). Towards the circular economy: Opportunities for the consumer goods sector. Vol. 2. The Ellen MacArthur Foundation.

The Ellen MacArthur Foundation, (2014). Towards the circular economy: Accelerating the scale-up across global supply chains. Vol. 3. The Ellen MacArthur Foundation.

The Ellen MacArthur Foundation, (2015). Growth within: a circular economy vision for a competitive Europe. The Ellen MacArthur Foundation.

The Ellen MacArthur Foundation, (2015). Towards a circular economy: Business rationale for an accelerated transition. Ellen MacArthur Foundation.

The World Bank, (2012). What a waste. A global review of solid waste management. Urban Development Series Knowledge Papers.

Tukker, A. \& Tischner, T. (2006). Product-services as a research field: past, present and future. Reflections from a decade of research. Journal of cleaner production, 14(17), pp. 1552-1556.

Tukker, A. (2015). Product services for a resource-efficient and circular economy - a review. Journal of Cleaner Production, 97, pp. 76-91.

Verschuren, P. J. M. \& Doorewaard H. (1999). Implementing Strategy. Utrecht: Lemma.

Webster, K. (2013). What might we say about a circular economy? Some temptations to avoid if possible. World Futures: The Journal of New Paradigm Research, 69(7-8), pp. 542-554.

Wilson, R.C. (2001) Ford spreads the word about its EMS success. Pollution Engineering 33(6), 32-33

WorlDynamics (Producer/Director). (2017). Circular Readiness Assessment Tool [Video file]. Retrieved from https://www.youtube.com/watch?v=Jy5yhiHPOhA

Zook, C. (2007). Finding your next core business. Harvard Business Review, 85(4), p.66-76. 